\title{
Mediation via International Organizations
}

\section{INTRODUCTION}

Several factors can increase the risk of war between states. But war primarily occurs when states believe (or, in fact, misbelieve, according to the Bargaining Model of War) that the likely benefits of combat outweigh the expected costs. Finding ways to prevent conflict in the first place - or a peaceful resolution to it once fighting has broken out-remains of vital interest to policymakers and scholars alike. If conflict belligerents cannot find a peaceful solution by themselves, international mediation is a frequently used tool. International mediation pertains to a third party getting involved in a dispute with the aim to ease the conflict peacefully for the belligerents. A mediator entering a conflict usually becomes part of it by manipulating the actors' behavior and, as a result, the choices the opposing parties have. But how can and do international organizations (IOs hereafter) mediate, and thus, alleviate a conflict? IOs frequently employ different methods than state mediators, including peaceful interventions aiming to improve states' relations or directly resolve rivalries. This article seeks to review the existing positivist literature on this and related questions. The review begins by offering definitions and a brief overview of the main components of the article, i.e., international mediation and IOs. The relevant work in the broader field of research is also discussed by looking at different methodological approaches: qualitative and quantitative studies. The article then proceeds by examining IOs' role in the international system more generally as I discuss some crucial studies dealing with the question of why states delegate (at least some) power to IOs in the first place. To this end, the review also illustrates some concepts that are necessary for the study and understanding of IOs, i.e., international cooperation more broadly defined, centralization, socialization, and compliance. Against this background, we are then able to address the link between mediation and IOs. In particular, the review illustrates the reasons why and how IOs mediate. These thought-provoking ideas offer an illustration of the role of IOs as mediators. The article finishes with an outlook of the consequences of mediation via IOs, particularly in light of the fact that mediators usually aim not only to reach a settlement, resolve the conflict, and produce a peace agreement, but also to secure post-conflict stability.

\section{GENERAL OVERVIEWS}

This review first discusses those studies that offer a general synopsis of this article, i.e., international mediation and IOs. It also addresses the underlying and broader research field of IOs and points to the literature dealing with methodological aspects, both quantitatively and qualitatively. This section thus provides the necessary background information, definitions, and literature. Based on this, we are then able to move to more detailed aspects of mediation employed by IOs.

\section{International Mediation}

Bercovitch, et al. 1991, p. 3 defines mediation as "a process of conflict management where disputants seek the assistance of, or accept an offer of help from, an individual, group, state, or organization to settle their conflict or resolve their differences without resorting to physical force or invoking the authority of the law." A similar definition is given by the comprehensive study Touval and Zartman 1985: mediation is "a mode of negotiation in which a third party helps the parties find a solution which they cannot find by themselves."

Examples of international mediation pertain to the efforts by the Organization for Security and Co-operation in Europe (OSCE) representative and Swiss Diplomat, Heidi Tagliavini, leading to the Minsk Protocol in 2014 or the North Atlantic Treaty Organization (NATO 
hereafter) trying to mediate in the Kosovo conflict at the end of the 1990s. Different actors can provide international mediation. A third-party mediator might be a state, a nongovernmental organization, a private individual, a representative from a religious or secular institution, or a regional or global IO (Crocker, et al. 1999, p. 6).

Bercovitch, Jacob, Theodore Anagnoson, and Donnette Wille. "Some Conceptual Issues and Empirical Trends in the Study of Successful Mediation in International Relations." Journal of Peace Research 28.1 (1991): 7-17.

One of the first systematic examinations of mediation. The paper focuses on (1) the nature of the disputing parties, (2) the nature of the dispute itself, (3) the identity and characteristics of the mediator, and (4) the strategies and tactics which the mediator employs. In addition, this paper provides one of the most commonly used definitions of international mediation.

Crocker, Chester, Fen Osler Hampson, and Pamela Aall. Herding Cats: Multiparty Mediation in a Complex World. Washington, DC: US Institute of Peace Press, 1999.

Based on a concise theoretical framework, the book comprises personal experiences of practitioners in the field of international mediation, working on bringing peace in significant conflicts across the world. Each chapter is a different case where each author delineates mediation processes, mediation processes, and the role of the actors involved in the conflict.

Touval, Saadia, and Zartman William, eds. International Mediation in Theory and Practice. Boulder, CO: Westview, 1985.

This edited volume discusses the basic concepts of international mediation, onset effectiveness, and the actors involved in a dispute. In the introductory chapter, one can find a widely used definition of mediation.

\section{International Organizations}

According to Pevehouse, et al. 2004, an IO consists of more than two member states and is usually established by a treaty. For example, the Treaty of Maastricht (signed by the parties in 1992) established the European Union in 1993. That treaty defines the mandate of an IO, which specifies its scope. An IO treaty thus delineates in advance the policy goals that the institution aims to achieve. For example, some IOs focus on security aspects, e.g., NATO, and others might focus on trade agreements, e.g., the World Trade Organization (WTO hereafter). IOs, finally, have rules and norms that are defined through their functioning and decision-making procedures. Hence, IOs vary along several dimensions including rules for membership, scope of issues covered, centralization of tasks, rules for controlling the institution, and flexibility of arrangements (Koremenos, et al. 2001). Along these lines, an IO might be of global scope, e.g., the United Nations (UN hereafter) or regional scope, e.g., the African Union (Hansen, et al. 2008). Abbott, et al. 2000 explains the design of IOs with regards to degrees of legalization that characterize IOs along three dimensions: obligation, precision, and delegation. The related work Abbott and Snidal 2000 links these dimensions to the broader categories of "soft" and "hard law."

Abbott, Kenneth, Robert Keohane, Andrew Moravcsik, Anne-Marie Slaughter, and Duncan Snidal. "The Concept of Legalization." International Organization 54.3 (2000): 401-419. The study focuses on the concept of legalization as a form of institutionalization. Legalization is characterized by three components: obligation, precision, and delegation.

Abbott, Kenneth, and Duncan Snidal. "Hard and Soft Law in International Governance." International Organization 54.3 (2000): 421-456.

The study examines the spectrum of IO design along legalization. It scales legalization from soft agreements to hard legal arrangements in light of the dimensions of obligation, precision, and delegation. 
Hansen, Holley, Sara Mitchell, and Stephen Nemeth. "IO Mediation of Interstate Conflicts: Moving beyond the Global vs. Regional Dichotomy." Journal of Conflict Resolution 52.2 (2008): 295-325.

The paper shows that IOs will be more successful conflict managers if they are highly institutionalized, if they have members with homogeneous preferences, and if they have more established democratic members.

Koremenos, Barbara, Charles Lipson, and Duncan Snidal. "The Rational Design of International Institutions." International Organization 55.4 (2001): 761-799.

The study introduces a theoretical framework for IOs based on the rational design project. The paper illustrates five features of institutions, i.e., membership, scope, centralization, control, and flexibility. To this end, the study explains the variation of these features in terms of indicators that characterize different cooperation issues, e.g., distribution, number of actors, enforcement, or uncertainty.

Pevehouse, Jon, Timothy Nordstrom, and Kevin Warnke. "The Correlates of War 2 International Governmental Organizations Data Version 2.0." Conflict Management and Peace Science 21.2 (2004): 101-119.

This article introduces the Correlates of War 2 International Governmental Organizations (IGOs) data. These data capture state memberships in the network of IOs from 1815 to 2005 in a time-series cross-section format.

\section{Quantitative and Qualitative Approaches}

Scholars have studied the topic of IO and mediation with different methods. Multiple approaches that combine diverse (theoretical and) methodological ways are necessary in order to derive findings that can improve our understanding of the practice and performance of mediation in a comprehensive way (Bercovitch 1996). On one hand, Crocker, et al. 2001 compiled a rich and detailed set of case studies on mediation, with a particular focus on multiparty mediation. The more recent work Bakaki 2016 describes mediation offered by NATO in the Cod Wars to make causal inferences regarding formal and informal mediation procedures. On the other hand, quantitative (large-N) studies seek to provide a general overview of the characteristics of IOs that increase the likelihood of conflict resolution. For instance, Bercovitch and Gartner 2006 thoroughly examined conflict management outcomes and suggested that mediating actors, the strategy they choose, and previous mediation experiences are some of the influential elements for the nature of a conflict management outcome. Bercovitch and Schneider 2000 examine the identity of mediators and the factors determining the choice of mediators. The authors test their hypotheses with a multivariate event count model using an original dataset on international mediation since 1950 and find that powerful states and IOs are the most prominent choices for mediators.

Bakaki, Zorzeta. "Deconstructing Mediation: A Case Study of the Cod Wars." Negotiation Journal 32.1 (2016): 63-78.

This study explores the mediation techniques used by NATO to settle the Cod Wars between Iceland and Britain. The analysis indicates that a combination of both formal and informal mediation techniques was key in resolving the Cod Wars.

Bercovitch, Jacob. Resolving International Conflicts: The Theory and Practice of Mediation. London and Boulder, CO: Lynne Rienner, 1996.

The book consists of an excellent collection of case studies on conflict resolution. In many of these cases, IOs have been the main mediators.

Bercovitch, Jacob, and Scott Sigmund Gartner. "Is There Method in the Madness of Mediation? Some Lessons for Mediators from Quantitative Studies of Mediation." International Interactions 32.4 (2006): 329-354. 
This is an article on the various types of conflict management outcomes and the mitigating influence of dispute intensity as drivers of mediation effectiveness.

Bercovitch, Jacob, and Gerald Schneider. "Who Mediates? The Political Economy of International Conflict Management." Journal of Peace Research 37.2 (2000): 145-165.

The purpose of this study is to identify the attributes of those actors who are most likely to mediate in international relations. The results indicate that the most powerful states and IOs dominate international conflict management.

Crocker, Chester, Fen Hampson, and Pamela Aall, eds. Turbulent Peace: The Challenges of Managing International Conflict. Washington, DC: US Institute of Peace Press, 2001.

This edited volume investigates recent conflicts and a broad set of conflict management strategies from a qualitative perspective. It offers answers on how best to prevent, manage, or resolve conflicts, with a particular focus on mediation.

\section{DELEGATING POWER TO INTERNATIONAL ORGANIZATIONS}

Literature in the field of IOs has particularly focused on the aspect of power delegation to "agents" (Tsebelis 2002, p. 238, Grant and Keohane 2005, Bradley and Kelley 2008). These agents are institutions (i.e., IOs) with expertise over specific matters. States give authority to IOs and let them take decisions on their behalf if they believe that they can derive more effectiveness or efficiency out of this (Barnett and Duvall 2005). This is why IOs have been studied as sets of rules, norms, and decision-making procedures that constrain and empower member states and, ultimately, serve to facilitate international cooperation. Additionally, literature refers to the aspects of centralization, socialization, and compliance as further consequences of delegating power to IOs. States join IOs for efficiency gains, legitimacy reasons, or, more generally, to reduce transaction costs (Pollack 2003, p. 29). Hawkins, et al. 2006 refers to the principal- agent theory to explain why states join IOs. That is, states (i.e., principals) delegate authority to IOs (i.e., agents) with expertise in specific areas. For example, the International Atomic Energy Agency (IAEA) promotes the peaceful use of atomic energy. Since many consequences of IOs, such as their performance in conflict resolution, are directly related to states' rationale on why delegating power in the first place, a thorough understanding of the latter is necessary for our assessment of IOs in the context of international mediation.

Barnett, Michael, and Raymond Duvall. "Power in International Politics." International Organization 59.1 (2005): 39-75.

This paper discusses the concept of power in interstate relations and suggests two dimensions of power: social relations through which power works and the specificity of social relations through which effects are produced. These distinctions lead to the taxonomy of power in four concepts: compulsory, institutional, structural, and productive power.

Bradley, Curtis, and Judith Kelley. "The Concept of International Delegation." Law and Contemporary Problems 71.1 (2008): 1-36.

The article offers a conceptualization of the institutional features of delegation. The different forms of delegations lie on the various costs and benefits that states get by delegating power to IOs.

Grant, Ruth, and Robert Keohane. "Accountability and Abuses of Power in World Politics." American Political Science Review 99.1 (2005): 29-43.

This article stresses the importance of accountability in the international system. It distinguishes between participation and delegation models of accountability. It identifies seven types of accountability mechanisms and considers their applicability to states, NGOs, multilateral organizations, multinational corporations, and transgovernmental networks.

Hawkins, Darren, David Lake, Daniel Nielson, and Michael Tierney, eds. Delegation and Agency in International Organizations. New York: Cambridge University Press, 2006. 
This book offers an analysis of the reasoning of states choosing to cooperate via IOs. An examination of different IOs such as the WTO, the UN, and the European Commission offers readers an understanding of how states try to fulfill their interests via IOs. The underlying theory is based on the principal-agent framework, which this study covers and summarizes nicely as well.

Pollack, Mark. The Engines of Integration? Delegation, Agency and Agenda Setting in the European Union. Oxford: Oxford University Press, 2003.

The book is an analysis of states' incentives to delegate power to EU bodies including the Commission, the Court of Justice, and the European Parliament and how this has affected the process of European integration.

Tsebelis, George. Veto Players: How Political Institutions Work. Princeton, NJ: Princeton University Press, 2002.

The book provides a thorough examination of states' interaction in IOs. Policy outcomes differ depending on who controls political power in the institution as well as on where the status quo is.

\section{International Cooperation}

IOs promote cooperation over different policy areas-depending on their expertise and scope - and thus are capable of reducing transaction costs. Hence, states can create links and establish and foster good relations via IOs. Cooperation among states, for instance, may include trade agreements or peace contracts, and these are usually promoted by, linked with, and heavily influenced by IOs (Dorussen and Ward 2008, Böhmelt 2009). Haftel 2013 finds that regional IOs implementing broad regional policies are more likely to have independent secretariats and strong dispute settlement. Literature has particularly focused on the benefits of international cooperation for dispute prevention and resolution. For example, Greig and Diehl 2006 highlights that a key aspect of alleviating disputes refers to the decrease of transaction costs. States that interact via different links face low transaction costs, and thus have a greater incentive to reach an agreement and not to abuse it in the future (Greig and Diehl 2006).

Böhmelt, Tobias. "International Mediation and Social Networks: The Importance of Indirect Ties." International Interactions 35.3 (2009): 298-319.

This study shows that although direct links can indicate mutual interests, shared preferences, and decreased uncertainty between warring parties, these ties either lose importance or become cut off when states enter a conflict. By contrast, indirect ties create a social network that involves outside parties in the dispute process, and indirect ties increase the exchange of information between belligerents and potential mediators and the chances that third parties will have a vital interest in intervention.

Dorussen, Han, and Hugh Ward. "Intergovernmental Organizations and the Kantian Peace: A Network Perspective.” Journal of Conflict Resolution 52.2 (2008): 189-212.

IOs memberships create network ties among states, allowing them, either individually or collectively, to intervene more effectively in latent conflicts. The IO network also provides direct and indirect communication channels, where indirect links can act as partial substitutes for direct diplomatic ties.

Greig, Michael J., and Paul Diehl. "Softening Up: Making Conflicts More Amenable to Diplomacy." International Interactions 32.4 (2006): 355-384.

The paper shows that states are more willing to use diplomatic alternatives when they bear high costs and have reason to expect good results from negotiation and mediation. In addition, positive interactions such as trading relationships and common IGO memberships are more effective at keeping states from becoming militarized rivals than they are in managing those conflictual relationships when they do occur. 
Haftel, Yoram. "Commerce and Institutions: Trade, Scope, and the Design of Regional Economic Organizations." The Review of International Organizations 8.3 (2013): 389-414. This research focuses on the design of regional economic IOs. It examines the impact of regional economic IOs on regional cooperation.

\section{Centralization}

Centralization refers to a concrete, stable, and supportive administrative apparatus (structure) of an institution. An IO is a very central authority if it has the institutional and structural capacity to directly support state interactions. In particular, Hooghe and Marks 2015 suggests that the authority of an IO is conditioned by two basic factors: the scale of its membership and the scope of its policy portfolio. Literature classifies states' interactions over the following actions offered by IOs: (1) negotiation forum, (2) fast response to sudden problems, (3) issue linkage, (4) precise terms for interactions, (5) secretariat, (6) supportive functions (e.g., background research). Abbott and Snidal 1998 explains that centralization fulfills various functions: facilitating the negotiations and implementations of agreements, managing or resolving disputes, offering technical assistance, elaborating norms, and shaping international discourse.

Abbott, Kenneth, and Duncan Snidal. "Why States Act through Formal International Organizations." Journal of Conflict Resolution 42.1 (1998): 3-32.

This article addresses the question of why states use formal organizations. It examines power and distributive questions and the role of IOs in creating norms and understanding. Centralization and independence are identified as the key properties of formal organizations, and their importance is illustrated with a wide array of examples.

Hooghe, Liesbet, and Gary Marks. "Delegation and Pooling in International Organizations." The Review of International Organizations 10.3 (2015): 305-328.

This paper theorizes that delegation and pooling are constrained by two basic design features: (1) the scope of an IO's policy portfolio and (2) the scale of its membership. The larger the organization, the more delegation and pooling exist. At the same time, when an IO has a broader mandate and policy focus, the members are more willing to delegate power to them.

\section{Socialization}

Hooghe 2005 (p. 865) refers to socialization as the process of inducting individuals into the norms and rules of a given community. A fundamental issue in the study of IOs is the emergence of social norms and how states adopt IOs' values and norms. Once states become part of an IO, they gradually adopt the social norms that an IO promotes (Kelley 2004). This is part of the socialization process, i.e., incorporating a new member into a society. Similarly, in the international system, socialization occurs when an IO accepts a new member. In turn, the new member will adopt the norms, values, attitudes, and behaviors accepted and practiced by an ongoing system (the IO in this case). In the international system, socialization occurs via two mechanisms: persuasion and social influence (Johnston 2001). This means that IOs directly influence states' decisions via persuasion and social influence. Social influence is made possible via the IO links that states generate with other member states. That is, states tend to behave similarly to their co-members in IOs. Common interests lead to common behavior and, thus, more cooperation and eventually less conflict. In essence, socialization is part of the range of behaviors that IOs promote in the international system to create balance and peaceful relations (Finnemore 1993, Bearce and Bondanella 2007).

Bearce, David, and Stacy Bondanella. "Intergovernmental Organizations, Socialization, and Member-State Interest Convergence.” International Organization 61.4 (2007): 703-733. 
This paper tests the institutional socialization hypothesis, arguing that IOs merge states' interests and guide them into common goals.

Finnemore, Martha. "International Organizations as Teachers of Norms: The United Nations Educational, Scientific, and Cultural Organization and Science Policy." International Organization 47.4 (1993): 565-597.

This study shows how IOs influence states' choices for domestic policies. State policies and structures are influenced by "intersubjective systemic factors," specifically by norms diffused within the international system.

Hooghe, Liesbeth. "Several Roads Lead to International Norms, but Few Via International Socialization: A Case Study of the European Commission." International Organization 59.4 (2005): 861-898.

The paper focuses on how time, organizational structure, alternative processes of preference formation, and national socialization influence international socialization.

Johnston, Alastair. "Treating International Institutions as Social Environments." International Studies Quarterly 45.4 (2001): 487-516.

The paper shows that persuasion and social influence determine whether actors will cooperate. It develops propositions about the social conditions under which one might expect to observe cooperation in institutions.

Kelley, Judith. "International Actors on the Domestic Scene: Membership Conditionality and Socialization by International Institutions." International Organization 58.3 (2004): 425457.

IOs aim to shape international politics, but at the same time they also influence domestic politics. This paper studies such arguments via case studies of the Baltic and Central European countries.

\section{Compliance}

Another institutional aspect of IOs refers to the element of compliance. Why do states comply with IOs' policies and laws (Chayes and Chayes 1993)? States usually have a genuine interest in complying with IOs due to the transaction cost argument, but they might fail in doing so, because of the lack of either willingness (e.g., private benefits) or opportunity (e.g., lack of capacity). Lake 2010 argues that high rates of compliance with international agreements are merely the by-product of states entering only those agreements with which they already intended to comply. Existing literature also refers to reputational costs, as states' reputational concerns are another central mechanism for states' compliance (Hafner-Burton 2008, DeMeritt 2012). States try to avoid the social stigma of non-credible actors, because this will prevent them from other cooperation in the future (Lebovic and Voeten 2006, Simmons 2010). An IO may also make use of the more direct avenues of enforcement in order to foster agreement compliance (i.e., sanctions). Enforcement may be necessary to prevent widespread defiance and, thus, the erosion of authority. In essence, both approaches - monitoring and enforcement - that an IO can employ to ensure compliance with post-conflict agreements rely on IOs' leverage and legitimacy (Chapman and Wolford 2010). Chapman, Terrence, and Scott Wolford. "International Organizations, Strategy, and Crisis Bargaining." The Journal of Politics 72.1 (2010): 227-242.

The study offers a game theoretical model to explain how IOs' decisions can affect a challenger state's costs for the outside option of war. The analysis shows that the aggregate effect of IO involvement on the likelihood of war depends on the strategic decisions of challengers to initially consult the organization.

Chayes, Abram, and Antonia Handler Chayes. "On Compliance." International Organization 47.2 (1993): 175-205. 
This study promotes the interdisciplinary study of international law and international relations in order to understand compliance with international agreements.

DeMeritt, Jacqueline. "International Organizations and Government Killing: Does Naming and Shaming Save Lives?” International Interactions 38.5 (2012): 597-621.

The study examines how naming and shaming via IOs influences governments. First, naming and shaming threatens leaders with immediate legal and/or economic punishment. Second, shaming threatens perpetrators with punishment. Finally, shaming threatens leaders by raising the risk of sending an order and having it subsequently disobeyed.

Hafner-Burton, Emilie. "Sticks and Stones: Naming and Shaming the Human Rights Enforcement Problem.” International Organization 62.4 (2008): 689-716.

This article examines the effectiveness of naming and shaming for making countries comply with human rights agreements. The paper analyzes the relationship between global naming-and-shaming efforts and governments' human rights practices for 145 countries from 1975 to 2000.

Lake, David. "Rightful Rules: Authority, Order, and the Foundations of Global Governance." International Studies Quarterly 54.3 (2010): 587-613.

The paper revaluates the study of authority in global governance. It suggests that global governance and its many forms can be understood and unified by a concept of relational authority, which treats authority as a social contract in which a governor provides a political order of value to a community in exchange for compliance by the governed with the rules necessary to produce that order.

Lebovic, James, and Erik Voeten. "The Cost of Shame: International Organizations and Foreign Aid in the Punishing of Human Rights Violators." Journal of Peace Research 50.4 (2006): 861-888.

This article argues that "shaming" in the UN Commission on Human Rights provided substantive information about rights abuses and gave political cover for the World Bank and other institutions seeking to sanction human rights violators.

Simmons, Beth. "Treaty Compliance and Violation." Annual Review of Political Science 13 (2010): 273-296.

This is a review of the literature in four issues areas in the field of international relations; security, war, and peace; international trade; protection of the environment; and human rights.

\section{INTERNATIONAL ORGANIZATIONS AS MEDIATORS}

On 3 October 2016, Turkey requested consultations with Morocco from the WTO regarding the imposition of definitive anti-dumping measures (see the online $*$ Chronological list of disputes cases[https://www.wto.org/english/tratop_e/dispu_e/dispu_status_e.htm This shows that many IOs offer dispute settlement mechanisms regardless of their mandate. Nonetheless, these types of mechanisms have not always been effective measures for conflict prevention and the restoration of peace. The primary challenge that IOs face into preventing conflict is the issue of resources (Ramsbotham, et al. 2011, p. 138). Additionally, Touval 1994 argues that the UN, due to its multilateral character, cannot coordinate a conflict and ultimately resolve it. On the contrary, the institutional structure of IOs offers techniques of conflict resolution which are not available from other actors, i.e., bargaining, information processing, and decision making (Snyder and Diesing 1978). The literature usually explains mediation along four main clusters of determinants: the likelihood of eventual mediation success, conflict management history, how domestic and international threats faced by the warring parties influence mediation onset, and the characteristics of the conflict dyad (Elgström, et al. 2003; Greig and Diehl 2006). IOs prevent conflict onset, but the scholarly work has also started exploring whether these same organizations help their members manage disputes 
(Kadera and Mitchell 2006). For instance, Boehmer, et al. 2004 argues that IOs require a certain degree of institutional structure in order to effectively intervene and resolve conflicts and, thus, divides IOs according to their degree of institutionalization: minimal (having meetings and information gathering), structured (having policy agendas), and interventionist (having mediation mechanisms). Additionally, Shannon 2009 highlights not only that IOs are interested in brokering peace to better provide collective goods, but that a number of IOs also formed with the explicit purpose of helping countries peacefully manage their grievances.

Boehmer, Charles, Erik Gartzke, and Timothy Nordstrom. "Do Intergovernmental Organizations Promote Peace?" World Politics 57.1 (2004): 1-38.

The effect of IO memberships on cooperation varies depending on institutional structure, mandate, and member cohesion. Specifically, IOs with security mandates and the most sophisticated institutional structures are likely to influence disputes.

Elgström, Ole, Jacob Bercovitch, and Carl Skau. "Regional Organizations and International Mediation: The Effectiveness of Insider Mediators." African Journal on Conflict Resolution 3.1 (2003): 11-27.

This paper explains why regional organizations are better in dealing with intrastate conflict than, for instance, the UN. Employing the case of the Economic Community of West African States (ECOWAS) interventions in West Africa, this study argues that regional organizations are well connected to the conflict at hand, and they have good knowledge about local conditions.

Greig, Michael J., and Paul F. Diehl. "Softening Up: Making Conflicts More Amenable to Diplomacy." International Interactions 32.4 (2006): 355-384.

Weak direct ties or hostile pre-conflict relations between belligerents undermine the willingness to talk, and therefore the chances of mediation. The study measures direct interconnections between belligerents by the number of shared IO memberships.

Kadera, Kelly M., and Sara McLaughlin Mitchell. "Heeding Ray's Advice: An Exegesis on Control Variables in Systemic Democratic Peace Research." Conflict Management and Peace Science 22.4 (2006): 311-326.

This study examines the role of international institutions in the relationship between the democratic community's strength and the use and effectiveness of third-party conflict management.

Ramsbotham, Oliver, Hugh Miall, and Tom Woodhouse. Contemporary Conflict Resolution. Cambridge, UK: Polity, 2011.

This book offers a comprehensive study of the theory and practice of conflict resolution. The first chapters provide an overview of the study of conflict resolution, origins, methods, types of conflicts, types of conflict management, and future perspectives on the field of conflict resolution. A chapter is dedicated to the role of IOs in preventing conflict and securing peace.

Shannon, Megan. "Preventing War and Providing the Peace? International Organizations and the Management of Territorial Disputes." Conflict Management and Peace Science 26.2 (2009): 144-163.

This paper examines whether IOs promote peaceful conflict management. Interventionist IOs encourage rival members to attempt peaceful conflict resolution. In addition, institutions do not promote bilateral negotiations between members, indicating that the socialization and trust-building capabilities of IOs are limited.

Snyder, Glenn Herald, and Paul Diesing. Conflict among Nations: Bargaining, Decision Making, and System Structure in International Crises. Princeton, NJ: Princeton University Press, 1978.

This book tests political behavior theories by comparing them with the historical record. Theories of bargaining, game theory, information processing, decision making, and 
international systems are applied to specific case studies of sixteen crises that occurred during a seventy-five-year period.

Touval, Saadia. "Why the UN Fails." Foreign Affairs 73.5 (1994): 44-57.

The study focuses on mediation that has been taken place by the UN. Although the UN has had some successful cases, the study claims that the UN is not the most appropriate mediator because it represents too many member states, it lacks the resources that are necessary for political leverage, and it does not offer credibility.

\section{Why Do International Organizations Mediate?}

IOs, like other mediators, have different motivations and rationales for their involvement (Greig 2005). For instance, IOs are able to facilitate bargaining and secure a solution for the belligerents due to resources, leverage, and legitimacy elements (Fearon 1998, Pevehouse and Russett 2006, Beardsley 2009). IOs are autonomous institutions with resources, and they are well equipped to monitor the behavior of member states (Tallberg, et al. 2013). Shannon, et al. 2010 notes that IOs have the leverage to impose sanctions on states that aim to renege on an agreement. In addition, the dilemma of a biased or a neutral mediator dominates the literature on mediation. To this end, Kydd 2006 highlights that credibility is an important element of successful mediation, since the parties need help from a reliable third-party actor. Another study by the same author, Kydd 2003, highlights that biased mediators are strong mediators in comparison to the neutral ones, who are generally less effective. Rauchhaus 2006 notes that although both impartial and biased mediators may, under certain conditions, prove effective, impartial mediators generally outperform biased ones. The institutional setting of IOs makes them credible mediators that are able to address information asymmetry (Powell 2002).

Beardsley, Kyle. "Intervention without Leverage: The Political Determinants of Weak Mediation." International Interactions 35.3 (2009): 272-297.

This paper examines why so many mediation attempts involve third parties with seemingly little leverage over the belligerents. Weak mediators are more likely when the conflict occurs on the periphery of the international system, but also when there are democratic neighbors. In addition, belligerents prefer weak mediation when there are incentives for their opponents to use mediation insincerely.

Fearon, James. "Bargaining, Enforcement, and International Cooperation." International Organization 52.2 (1998): 269-305.

The paper shows that commitment problems and relative gains are not the only issues that generate rivalries among actors. A game model is employed to show that bargaining decreases the "shadow of the future."

Greig, J. Michael. "Stepping into the Fray: When Do Mediators Mediate?" American Journal of Political Science 49.2 (2005): 249-266.

This article examines the conditions that promote the request, offer, and occurrence of mediation between enduring rivals. The characteristics of the disputants and the presence of ongoing disputes also impact the occurrence of mediation.

Kydd, Andrew. "Which Side Are You On? Bias, Credibility, and Mediation." American Journal of Political Science 47.4 (2003): 597-611.

This study claims that neutrality is not a necessary element of a successful mediator. Specifically, in order to be believed when she provides information, a mediator must be biased. An unbiased mediator who simply wants to prevent conflict will not be credible to the parties involved in the negotiations because she could not be trusted to send messages that might increase the likelihood of conflict.

Kydd, Andrew. "When Can Mediators Build Trust?" American Political Science Review 100.3 (2006): 449-462. 
The paper presents a formal model of international mediation. Mediators can be credible if they care about the issue at stake, have a moderate ideal point, and do not find conflict to be too costly.

Pevehouse, Jon, and Bruce Russett. "Democratic International Governmental Organizations Promote Peace.” International Organization 60.4 (2006): 969-1000.

This study challenges the realist hypothesis that IOs are fundamentally irrelevant to reducing violent international conflict. IOs whose members are democratic states are strongly and consistently associated with a lower risk of fatal militarized disputes.

Powell, Robert. "Bargaining Theory and International Conflict." Annual Review of Political Science 5.1 (2002): 1-30.

This paper revises the argument that the origins, conduct, and termination of war comprise a bargaining process. Additionally, it aims to extend this argument to multilateral bargaining, the effects of domestic politics in international outcomes, understanding intrawar bargaining, and the dynamic of commitment problems.

Rauchhaus, Robert. “Asymmetric Information, Mediation, and Conflict Management.” World Politics 58.2 (2006): 207-241.

A game theoretical model and a statistical analysis examine mediation in conflicts. Provision of asymmetric information is a highly effective strategy for conflict resolution. The overall results show that impartial mediators outperform biased ones.

Shannon, Megan, Daniel Morey, and Frederick Boehmke. "The Influence of International Organizations on Militarized Dispute Initiation and Duration." International Studies Quarterly 54.4 (2010): 1123-1141.

This paper examines the impact of IOs on militarized interstate dispute durations between 1950 and 2000. IOs mitigate commitment problems and encourage belligerents to cease problems faster.

Tallberg, Jonas, Thomas Sommerer, Theresa Squatrito, and Christer Jönsson. The Opening Up of International Organizations. Cambridge, UK: Cambridge University Press, 2013.

This is an analytical framework for the role and impact of IOs in world politics. IOs are institutions with various roles and mandates. They engage transnational actors as policy experts, service providers, and stakeholder representatives.

\section{How Do International Organizations Mediate?}

IOs have different mechanisms to prevent conflict or alleviate conflict (Russett, et al. 1998). Literature generally distinguishes between the passive and active role of IOs. On one hand, IOs are active mediators when they try to resolve a conflict by getting directly involved in peace and conflict bargaining (Mitchell and Hensel 2007). IOs help states to implement policies aiming to build peaceful relations among their members through enforcement, management, and authoritarian approaches (Joachim, et al. 2007, pp. 6-10). Hence, the active involvement of IOs in the conflict management process includes both facilitative intervention - in the form of good offices, mediation, conciliation, and fact finding - and binding intervention in the form of arbitration or adjudication (Gent and Shannon 2010). For example, IOs ease conflicts when they employ binding methods to increase commitments to and thus non-violation of an agreement, and they systematically provide arbitration and adjudication (Gent and Shannon 2010, Gent and Shannon 2011). IOs manipulate actors' decisions by presenting the costs and benefits of war; they provide solutions to states' arguments or transmit information that will make the actors reluctant to fight. IOs act as mediators by providing information to both sides, reducing uncertainty while giving incentives to the parties to reach an agreement in order to establish peace in the system (Keohane 1984, Young 1972). Long, et al. 2007 adds that IOs, broadly speaking, are formed to encourage bargaining between their members by providing information and lowering 
transaction costs. Furthermore, IOs provide resources and expertise that can be used for bargaining and offering incentives for cooperation (Convergne 2016). On the other hand, IOs also influence interstate bargaining more passively through the pressure they exert on member states to settle their disagreements peacefully. Though IOs do not directly serve as mediators, they lengthen the shadow of the future and raise reputational costs for treaty violation (Haftel 2007, Mitchell and Hensel 2007).

Convergne, Elodie. "Learning to Mediate? The Mediation Support Unit and the Production of Expertise by the UN." Journal of Intervention and Statebuilding 10.2 (2016): 181-199.

This study explains the role of the UN Mediation Support Unit (MSU). The purpose and the actions of the MSU are rather generic due to the institutional design within the Secretariat.

Gent, Stephen, and Megan Shannon. "The Effectiveness of International Arbitration and Adjudication: Getting into a Bind.” The Journal of Politics 72.2 (2010): 366-380.

This is an analysis of the importance of the type of conflict management techniques in resolving a conflict. It examines several techniques and finds that binding approaches are more effective than nonbinding or bilateral negotiations.

Gent, Stephen, and Megan Shannon. "Decision Control and the Pursuit of Binding Conflict Management: Choosing the Ties That Bind." Journal of Conflict Resolution 55.5 (2011): 710-734.

This study examines binding conflict management techniques-i.e., arbitration and adjudication - and their effectiveness at resolving conflicts. Three factors influence the willingness of states to give up decision control: issue salience, availability of outside options, and history of negotiations.

Haftel, Yoram. "Designing for Peace: Regional Integration Arrangements, Institutional Variation, and Militarized Interstate Disputes." International Organization 61.1 (2007): 217-237.

This study examines the effect of IOs on violent conflict by providing an empirical analysis pertaining to the effect of institutional variation on violent conflict. The scope of economic activity and regular meetings of high-level officials are significant to a peaceful resolution of disputes.

Joachim, Jutta, Bob Reinalda, and Bertjan Verbeek, eds. International Organizations and Implementation: Enforcers, Managers, Authorities? Oxford: Routledge, 2007.

A series of chapters in this edited volume show under what circumstances IOs are enforcers, managers, or authorities over states' violations. Overall, IOs are able not only to pursue such roles separately but also to combine them in order to maximize the effects of a policy.

Keohane, Robert. After Hegemony: Cooperation and Discord in the World Political Economy. Princeton, NJ: Princeton University Press, 1984.

This book presents an extensive discussion on the origins of international cooperation and how it evolved during the different phases of world politics. It offers a theory on the existence of mutual interests and examines further the conditions under which these interests lead to cooperation.

Long, Andrew, Timothy Nordstrom, and Kyeonghi Baek. "Allying for Peace: Treaty Obligations and Conflict between Allies." Journal of Politics 69.4 (2007): 1103-1117.

The study examines which aspects of alliance treaties impact on intra-alliance disputes. The results show that conflicts between allies are less likely to occur when the alliance treaty includes mechanisms to signal peaceful intentions and increase transparency.

Mitchell, Sara, and Paul Hensel. "International Institutions and Compliance with Agreements." American Journal of Political Science 51 (2007): 721-737.

This is a quantitative empirical analysis of the relevance of international institutions for resolving contentious interstate issues both actively and passively. 
Russett, Bruce, John Oneal, and David Davis. "The Third Leg of the Kantian Tripod for Peace: International Organizations and Militarized Disputes, 1950-85." International Organization 52.3 (1998): 441-467.

This study illustrates what is the network of IOs and why IOs matter. It shows that IOs formulate norms, help at resolving disputes among their members, reduce uncertainty, and promote socialization.

Young, Oran. "Intermediaries: Additional Thoughts on Third Parties." Journal of Conflict Resolution 16.1 (1972): 51-65.

The study examines the pertinence and functions of third parties, along with the incentives and bargaining they employ. The findings suggest that (1) third parties have a variety of functions that can benefit the belligerents, (2) there are always costs and benefits for a third party to intervene in a conflict, and (3) bargaining is a plausible option.

\section{CONSEQUENCES OF INTERNATIONAL ORGANIZATION MEDIATION}

IOs often get involved in dispute settlement aiming to shorten the duration of a conflict, produce a peace agreement, or resolve the conflict completely and thus induce a durable settlement (Hartzell, et al. 2001). A stream of literature has focused on what makes mediation effective, and another aspect of the literature discusses the mechanisms that enhance postconflict stability. To this end, Diehl 2003 not only presents conflict management techniques but also describes strategies that secure post-conflict stability and peace duration. Another study, Regan and Stam 2000, focuses on the role of timing of conflict management efforts and explains that the effects of mediation vary over the course of a dispute.

Diehl, Paul. "Regional Conflict Management: Strategies, Necessary Conditions and Comparative Effectiveness." In Regional Conflict Management. Edited by Paul Diehl and Joseph Lepgold. Lanham, MD: Rowman and Littlefield, 2003.

This chapter examines broad categories of conflict management, enforcement, peacekeeping, and peacemaking and how each of these can promote regional conflict management.

Hartzell, Caroline, Matthew Hoddie, and Donald Rothchild. "Stabilizing the Peace after Civil War: An Investigation of Some Key Variables." International Organization 55.1 (2001): 183-208.

The study examines elements that promote durable peace. The most durable settlements are likely to be those that (1) concern former democratic states, (2) involve low-intensity, longterm civil conflicts, (3) include in the peace agreement provisions for the territorial autonomy of threatened groups, and (4) have security assurances offered to the former combatants by third-party states or regional IOs.

Regan, Patrick, and Allan Stam. "In the Nick of Time: Conflict Management, Mediation Timing, and the Duration of Interstate Disputes." International Studies Quarterly 44.2 (2000): 239-260.

The study examines the relationship between the timing of conflict management procedures and dispute duration.

\section{Effective Mediation}

Several characteristics determine mediation success. The nature of the dispute, the characteristics of the belligerents and the mediator, the costs of conflict, and the links among all relevant parties can eventually affect the mediation outcome. Along these lines, Beardsley 2011 argues that mediation is often a long and complicated process that might lead to different outcomes. To date, scholarly examination of conflict resolution has focused on the effectiveness of conflict management, on different styles of conflict management, or on actors' choices. Beardsley, et al. 2006 argues that manipulation among the conflict 
management techniques (i.e., manipulation, facilitation, formulation) has the greatest impact on crisis settlement. Referring to the type of mediator, Svensson 2009 claims that biased mediators increase the likelihood of reaching a peace agreement. That is, information provision, decreasing transaction costs, and addressing commitment problems are the elements that enhance IOs' mediation capabilities and thus increase the likelihood of mediation success (Dorussen and Ward 2010). The literature has particularly focused on the mediation effectiveness of regional organizations (e.g., Al-Marashi 2008, Pinfari 2009, Gartner 2011). Nathan 2010 highlights that the effectiveness of regional IOs depends on historical, geographic, political, and economic circumstances. Nguyen 2002 points out the need for local mediation efforts (i.e., regional organizations) before calling in the UN.

Al-Marashi, Ibrahim. "Regional Organizations as Conflict Mediators? The Arab League and Iraq." In Beyond Regionalism? Regional Cooperation, Regionalism and Regionalization in the Middle East. Edited by Cilija Harders and Matteo Legrenzi. Oxford: Ashgate, 2008.

The chapter refers to the role of regional organizations as mediators in conflicts. It particularly focuses on the mediation strategy of the League of Arab States in Iraq.

Beardsley, Kyle, David Quinn, Bidisha Biswas, and Jonathan Wilkenfeld. "Mediation Style and Crisis Outcomes." Journal of Conflict Resolution 50.1 (2006): 58-86.

This study focuses on the effects of different mediation styles-i.e., facilitation, formulation, and manipulation-on resolving international crises. Effectiveness is categorized in three dimensions; formal agreement, post-crisis tension reduction, and contribution to crisis abatement.

Beardsley, Kyle. The Mediation Dilemma. New York: Cornell University Press, 2011.

This book is a thorough analysis of mediation. Third-party interveners might often be successful when mediating, but there are also issues that may arise, such as time inconsistency problems; when is best to mediate? This is why the author posits mediation as a dilemma.

Dorussen, Han, and Hugh Ward. "Trade Networks and the Kantian Peace." Journal of Peace Research 47.1 (2010): 29-42.

This study examines the pacifying effects of international trade. Direct and indirect links generated via trade flows decrease interstate conflict.

Gartner, Scott Sigmund. "Signs of Trouble: Regional Organization Mediation and Civil War Agreement Durability." The Journal of Politics 73.02 (2011): 380-390.

This study examines theoretically and empirically the effectiveness of regional organizations in international mediation efforts. In particular, selection effects as driven by the nature of the conflict and the identity of the mediator are highlighted in this work.

Nathan, Laurie. The Peacemaking Effectiveness of Regional Organisations. Crisis States Working Papers Series No. 2. London: Crisis States Research Centre, 2010.

The article examines the role of regional organizations in preventing and alleviating conflict. It particularly discusses several cases of regional organizations, e.g., the EU, the Association of Southeast Asian Nations (ASEAN).

Nguyen, Thi Hai Yen. "Beyond Good Offices? The Role of Regional Organizations in Conflict Resolution." Journal of International Affairs 55.2 (2002): 463-484.

The study discusses the cases of ASEAN and the Organization of American States (OAS) dealing with the conflicts in Cambodia and Haiti, respectively.

Pinfari, Marco. Nothing but Failure? The Arab League and the Gulf Cooperation Council as Mediators in Middle Eastern Conflicts. Crisis States Working Papers Series No. 2. London: Crisis States Research Centre, 2009.

This paper is thorough overview of the Arab League; discusses the institutional concerns and problems that emerged over the course of the years. 
Powell, Robert. "War as a Commitment Problem." International Organization 60.1 (2006): 169-203.

This paper explains via a formal theoretical model why war occurs. Information asymmetry is one of the key issues. It isolates the study of commitment problems from informational problems and offers two mechanisms that impact on the risk of war.

Svensson, Isak. "Who Brings Which Peace? Neutral versus Biased Mediation and Institutional Peace Arrangements in Civil Wars." Journal of Conflict Resolution 53.3 (2009): 446-469.

This study examines the different types of mediators (i.e., neutral, government-biased, and rebel-biased mediators) and the content of peace agreements.

\section{Post-conflict Stability}

Among the biggest challenges of mediation is not only to reach a successful outcome, a settlement, or a peace agreement, but also to make sure that the settlement lasts and the rivals will not get involved in another conflict (Vasquez 2000, p. 335, Regan and Aydin 2006). IOs usually employ instruments such as monitoring to make sure that a state will not violate an agreement (Tallberg 2002, Glennon 2003). Schultz 2010, for instance, argues that agreements by themselves cannot guarantee that violence will not break out again, unless there are concessions by the target state and/or monitoring mechanisms. However, Beardsley 2008 argues that mediators do not have the capacity to impact on peace after hostilities terminate and, actually, promote agreements that are more likely in the long run to fade. This ultimately raises the need for monitoring and enforcement. Doyle and Sambanis 2006 (p. 53) contends that the UN considered necessary not only the intervention for resolving a conflict but also the reassurance of post-conflict stability.

Beardsley, Kyle. "Agreement without Peace? International Mediation and Time Inconsistency Problems." American Journal of Political Science 52.4 (2008): 723-740.

The study examines the short- and long-term effects of mediation. Although mediation offers stability in the short term, violence breaks out again in the long run. Ultimately, the promising of monitoring and enforcement creates incentives for the actors to arrive at solutions that are not durable.

Doyle, Michael, and Nicholas Sambanis. Making War and Building Peace: United Nations Peace Operations. Princeton, NJ: Princeton University Press, 2006.

The book offers an analytical overview of the role of the UN in resolving conflicts and restoring and maintaining peace. It enhances our understanding of UN peacekeeping operations and post-conflict stability by comparing cases that experienced UN peacekeeping operations and others that did not.

Glennon, Michael. "Why the Security Council Failed." Foreign Affairs 82 (2003): 16.

The study is an overview of the Security Council actions concerning the US invasion of Iraq. The UN's rules governing the use of force, laid out in the charter and managed by the Security Council, had fallen victim to geopolitical forces.

Regan, Patrick, and Aysegul Aydin. "Diplomacy and Other Forms of Intervention in Civil Wars." Journal of Conflict Resolution 50.5 (2006): 736-756.

This study examines how interventions affect the duration of civil war. Employing statistical analysis and a duration model makes two suggestions on this aspect. First, diplomacy is critical to conflict management and, second, the timing of the diplomatic attempt is just as important as diplomacy itself.

Schultz, Kenneth. "The Enforcement Problem in Coercive Bargaining: Interstate Conflict over Rebel Support in Civil Wars." International Organization 64.2 (2010): 281-312.

The study examines the role of enforcement in reducing violence after the disputants have reached an agreement. It identifies that imperfect monitoring impacts on enforcement 
efforts but that this is often influenced by the parties' preferences about monitoring. Such monitoring processes are often employed by IOs in helping to reduce violence.

Tallberg, Jonas. "Paths to Compliance: Enforcement, Management, and the European Union." International Organization 56.3 (2002): 609-643.

The paper challenges the notion that enforcement and management are competing strategies for achieving compliance. Instead, a combination makes the EU highly successful in combating violations, thus reducing noncompliance to a temporal phenomenon.

Vasquez, John, ed. What Do We Know about War? Lanham, MD: Rowman \& Littlefield, 2000.

This edited volume offers an overview from various scholars about our knowledge and understanding of war. It identifies and analyzes those factors that promote the outbreak of interstate war on one hand and those factors that promote peace on the other. 